\title{
Brachial thrombosis in a mare
}

\author{
Richard P. C. Coomer, G. Barrie Edwards, Astrid B. M. Rijkenhuizen' and Udo Hetzel²
}

Equine Division, Faculty of Veterinary Science, University of Liverpool, United Kingdom, Department of Equine Sciences, Utrecht University, the Netherlands ${ }^{1}$ and Department of Pathology, Faculty of Veterinary Science, University of Liverpool, United Kingdom²

\begin{abstract}
Summary
An 11 -year old lrish draft cross mare was presented with a severe right fore limb lameness, profuse sweating and colic-like symptoms. The mare did not improve to phenylbutazone nor sedation. She continually rested the right fore and was unable to bear weight. The agitation of the mare made further examination too dangerous to perform and she was anaesthetised for further examination. The only clinical abnormality noted was significant asymmetry in the surface temperature of the forelimbs: the left fore felt warm with recent sweat but the right was cold to the touch. Doppler ultrasonography of the medial aspect of both forearms adjacent to the radius and the palmar aspect of the fetlocks revealed no arterial flow on the right. A diagnosis of arterial occlusion was made and the mare euthanased on humane grounds, 4 hours after the precipitation of clinical signs. Postmortem examination revealed thrombosis of the brachial artery and its distal branches, a cause of forelimb lameness never previously reported in the literature. Histopathological examination indicated that the thrombus predated the onset of clinical signs, but how long it had actually taken to develop was impossible to assess. Physical removal of the thrombus was discounted due to the inability to visualise the proximal extent of the thrombus as well as the severe clinical signs. The possible causes of thrombosis are discussed.
\end{abstract}

Keywords: Thrombosis, equine, Brachial artery, lameness

\section{Brachialthrombose bei einer Stute}

Eine 11 Jahre alte Irisch Kaltblut-Stute zeigte hochgradige Lahmheit der rechten Vordergliedmaße, profuses Schwitzen und kolikähnliche Symptome. Der Zustand besserte sich weder nach Phenylbutazon noch nach Sedierung. Das Tier belastete die rechte Vorhand nicht. Die Stute war für eine weitere gründliche klinische Untersuchung zu unruhig und wurde deshalb in Narkose gelegt. Die einzige klinische Auffälligkeit war deutlich unterschiedliche Hauttemperatur beider Vordergliedmaßen: die linke Seite fühlte sich warm an und war schweißnass, die rechte Seite war kalt. Die Doppler-Ultraschalluntersuchung des medialen Bereich von Karpal- und Fesselbereich beider Vordergliedmaßen ergab auf der rechten Seite keinen Blutfluss. Die Diagnose lautete auf arteriellen Verschluss. Die therapeutische Entfernung des Thrombus erschien unmöglich, weil die proximale Ausdehnung der Thrombosierung nicht zu erkennen war Aus diesem Grunder und angesichts der hochgradigen Lahmheit wurde die Stute euthanasiert. Die Sektion ergab eine ausgedehnte Thrombose der Brachialarterie und ihrer distalen Äste. Ein solcher Befund ist bisher als Lahmheitsursache in der Literatur nicht beschrieben. Die histologischen Befunde wiesen darauf hin, dass die Thrombose den klinischen Anzeichen vorausging, aber es war nicht möglich zu sagen, wieviel Zeit die Entwicklung der Thrombose in Anspruch genommen hatte. Im Beitrag werden die möglichen Ursachen der Thrombose.

Schlüsselwörter: Thrombose, A. brachialis, Lahmheit

An 11 -year old Irish draft cross mare was presented for examination and treatment of severe pain with distress. It had been in the owner's possession for 5 years and was used for general riding duties. There was no previous history of lameness or exercise intolerance and the mare was in light work. Sudden onset grade 3/10 right forelimb lameness was investigated by the referring vet; no clinical abnormalities could be detected and the lameness was abolished following perineural anaesthesia of the palmar digital nerve at the level of the proximal sesamoid bones. Radiographs had been consistent with a degenerative joint disease process within the proximal and distal interphalangeal joints. The mare was box rested for 5 days prior to further investigation. On the day of referral, intra-articular analgesia of the distal interphalangeal joint was carried out. The mare was placed in a stable and was found severely agitated 5 minutes later, sweating profusely and attempting to roll. She was unwilling or unable to bear weight on the blocked limb. Phenylbutazone (2500 mg) was administered intravenously, followed shortly after with 30 mg butorphanol, with little evident improvement in the mare's comfort. A rectal examination was carried out but no abnormalities were detected. Given the severe agitation of the mare and the close proximity to hospital facilities the mare was referred for further assessment and treatment.

On arrival the mare was severely agitated with profuse sweating and frequent attempts to roll. She continually rested the right fore and was unable to bear weight. Heart rate was 80 beats/minute and no gut sounds were auscultated. Xylazine ${ }^{a}$ (300 mg) was administered intravenously with no change in the condition. A provisional diagnosis of bone fracture was made, possibly a complication of diagnostic anaesthesia. The agitation of the mare made further examination too dangerous to perform; it was therefore carried out after induction of general anaesthesia. No instability, heat or crepitus was palpated at any point on the right fore limb and multiple radiographs failed to demonstrate evidence of any bone fracture. Palpation of the limb demonstrated a significant asymmetry in surface temperature: the left fore felt warm with recent sweat, but the right was cold to the touch. Doppler ultrasound exa- 
mination was carried out over the medial aspect of both forearms adjacent to the radius and the palmar aspect of the fetlocks where the neurovascular bundle was easily palpable. In both locations normal arterial flow was visible on the left, but with no corresponding flow on the right (Fig. 1a,b). Systemic blood samples were obtained which demonstrated mildly elevated creatinine kinase at $578 \mathrm{iu} / \mathrm{L}$ (normal 2.4-23.4). No other abnormalities were noted in serum biochemical values and clotting times were within normal limits. A diagnosis of arterial occlusion was made and the mare euthanised on humane grounds. The time of euthanasia was 4 hours after the precipitation of clinical signs.
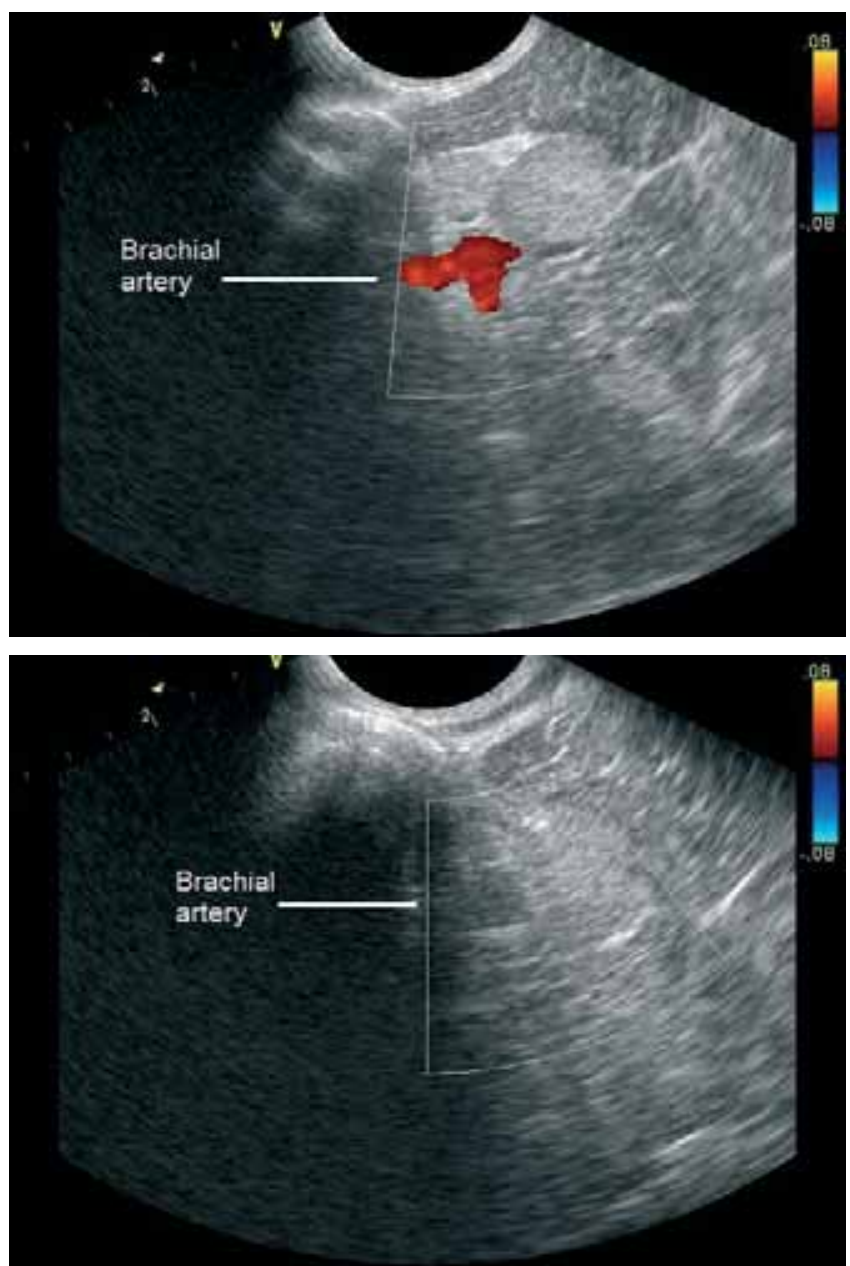

Figs 1 $\mathbf{a}$ and b: Transverse colour Doppler ultrasound images taken on the medial aspect of the left and right forearms respectively. Blood flow can be seen in the brachial artery on the left, adjacent to the deep digital flexor muscle. None is visible at the equivalent position on the right; instead, there is a hypoechogenic mottled area, representing arterial thrombus.

Transversaler Doppler-Ultraschall des medialen Bereichs beider Vordergliedmaßen. Links zeigt sich Blutfluss entlang des tiefen Zehenbeugers, nicht jedoch rechts. Stattdessen stellt sich der Thrombus als fleckig hypoechogener Bereich dar.

During full postmortem examination, the brachial artery and its distal branches were found to be firm and swollen on the right side (Fig. 2), compared to the left. Red discoloration was visible over the outer surface of the brachial artery and its adjacent vein at the level of the shoulder joint. After careful removal of the artery, a mature thrombus was found originating at the point of discolouration, adhering and occluding the brachial artery (Fig 4). All distal branches were likewise occluded by more friable thrombus material; the thrombus did not extend further proximal than the area of discolouration. No internal abnormalities were found within the brachial vein. These arterial changes were in complete contrast to the left fore, where the arteries were soft and elastic and within which the blood had not clotted (Fig. 3). No cardiac abnormalities were seen, nor was any evidence of bone fracture found.

Serial cross sections were obtained from 9 locations along the length of the normal left and thrombosed right arteries (Figs. 3) for histopathological examination (Figs. 5 and 6). No

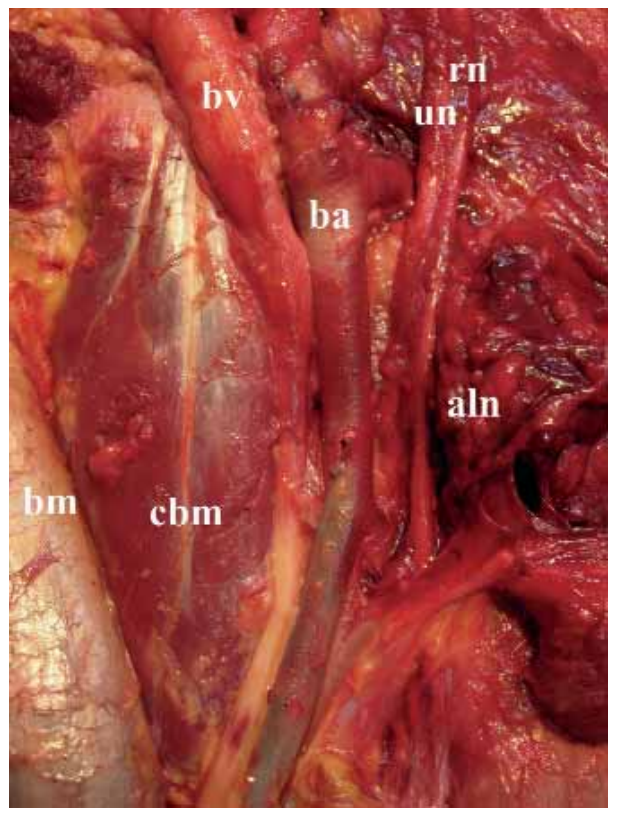

Fig 2 Photograph of the proximal medial aspect of the right fore after dissection. The brachial artery (ba) can be seen next to the brachial vein (bv), the ulnar and radial nerves (un and $\mathrm{rn}$ respectively) and the coracobrachialis muscle (cbm). Anatomical landmarks include axillary lymph node (aln) and biceps muscle $(\mathrm{bm})$. The artery had a purple colour and contained firm thrombus as far as the proximal carpus, whereas the left fore was pink and flexible and contained no thrombus.

Sektionsbild des proximomedialen Bereichs der rechten Vordergliedmaße. Die A. brachialis (ba) zeigt sich neben V. brachialis (bv), Nn. radialis (nr) und ulnaris (nu) sowie M. coracobrachialis (cbm). Anatomische Orientierungspunkte sind die Axillarlymphknoten (aln) und $\operatorname{der}$ M. biceps $(\mathrm{bm})$. Die Arterie ist von violetter Farbe und enthält über die Ausdehnung des proximalen Karpus einen festen Thrombus.

abnormalities were noted in any section taken from the left arterial tree. On the right, no abnormalities were observed in either the arterial wall or lumen in the most proximal section, taken $4 \mathrm{~cm}$ proximal to the bifurcation of the subscapular artery. In the remaining distal sections the intima demonstrated moderate activation of endothelial cells, with focal endothelial denuding and necrosis (Fig 6). Moderate focal subendothelial oedema, haemorrhage and mixed cellular infiltrate of neutrophils, lymphocytes, plasma cells and eosinophils were apparent. Mediacytes exhibited moderate cytoplasmic vacuolation, typical of degeneration. The material occluding the arterial lumen was composed of mature thrombus of uniform density, consisting of erythrocytes, leucocytes, fibrin, cellular debris and with occasional areas of mild haemosiderosis (Fig 5a). Martius-scarlet blue staining was red, 
which indicated a thrombotic lesion greater than 16 hours of age (Fig. 5b). No embolic material, e.g. bacteria, was observed in any section.

Vascular rupture following long bone fracture could produce the same clinical signs. A report of a fractured femur described a transected popliteal artery, causing similar ischaemic necrosis of the distal limb (Rose et al 1984). However, this aetiology was excluded at post-mortem in favour of primary obstruction by thrombus. A thrombus is formed when blood clots inappropriately within the circulation and the significance is both the occlusion of the vessel at the site of formation

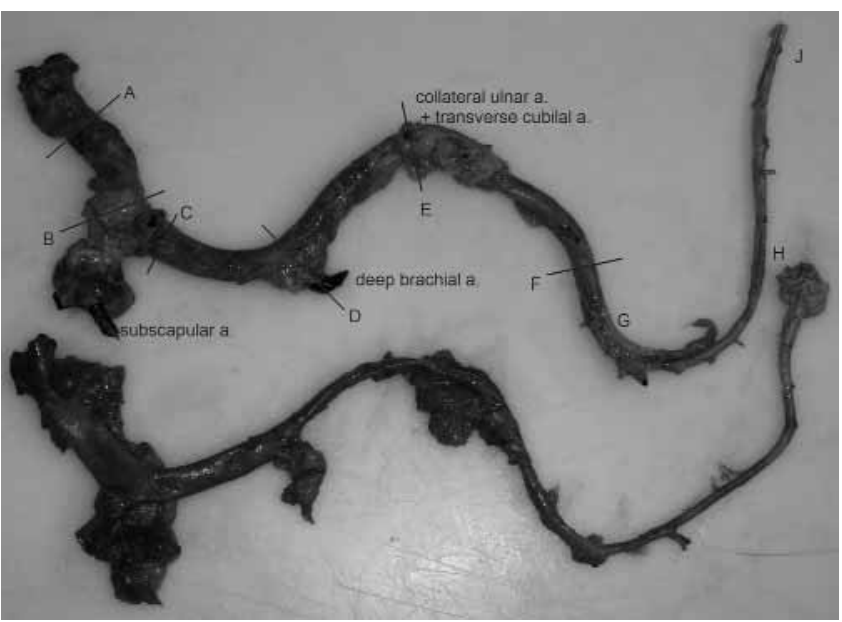

Fig 3 Gross appearance of the right and left axillary artery and brachial artery. The diameter of the right brachial artery is increased. Letters (A-I) mark the section of transverse histological sampling. Sektionspräparat der rechten un linken A. brachialis. Der Durchmesser der rechten Arterie ist vergrößert. Die Buchstaben (A-I) markieren die histologischen Querschnitte.

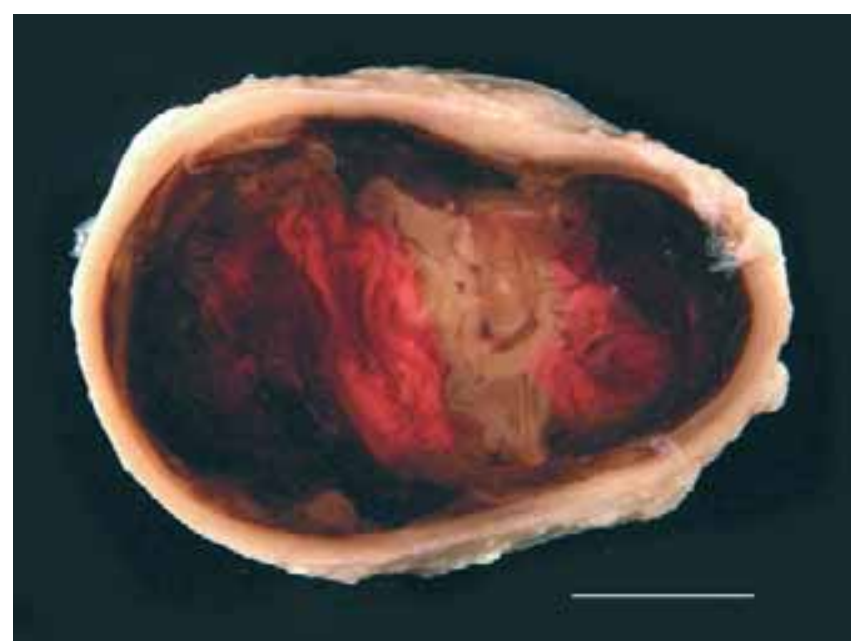

Fig 4 Gross sectional appearance of section C after fixing in $10 \%$ formalin, prior to histopathological sectioning. Bar $5 \mathrm{~mm}$.

Präparatquerschnitt aus Sektion C nach Fixierung in 10\% Formalin vor dem histologischen Schnitt. Maßstab $5 \mathrm{~mm}$.

and the possibility of embolisation of fragments, causing downstream ischaemic infarction. In man, $75 \%$ of arterial emboli occur within the lower limb, $10 \%$ within the brain, with visceral organs and the upper limb much less commonly affected (Mitchell and Cotran 2003). In horses, arterial thrombus formation is commonly charted at a number of sites, including cranial mesenteric artery, aorta and the iliacfemoral arteries. The latter is known as aorto-iliac thrombosis (AIFT), first described as a cause of intermittent lameness in 1907 (Merillat and Merillat). The effect of AIFT is summarised as the five ' $p$ 's: pain, pallor, poikilothermy, pulselessness and paresis clinical signs depend on the degree of vascular occlusion (Jubb et al. 1993). Although this case most closely resembles AIFT, a number of important differences were seen. Lameness in AIFT is progressive, being initially mild in response to exercise and rapidly resolving, even the most severe cases of which resolve within 1-2 hours (Edwards and Allen 1988). This is thought to be due to the facility of the hind limb's collateral circulation to prevent prolonged venous stasis and ischaemic insult. Only in the most advanced cases can AIFT lameness approach that exhibited by the mare described here, in this case seemingly precipitated whilst on box rest and following a short trot-up. The facility of the forelimb to develop collateral circulation is unknown. The thrombus was older that the onset of clinical signs, but how long it had taken to develop was impossible to assess. Either the collateral circulation in the forelimb is poor, or the thrombus had developed relatively quickly. There are three primary influences recognised which act together to predispose to thrombus formation, the so-called Virchow triad (Mitchell and Cotran 2003). These are (1) endothelial injury, (2) stasis or turbulent blood flow and (3) blood hypercoagulability.

Endothelial injury is a particularly important cause of cardiac and arterial thrombus formation in man, because physical loss of endothelium exposes the sub-endothelial collagen and triggers the clotting cascade. Typically, thrombus forms over myocardial infarcts, diseased heart valves or within diseased arteries; around $80 \%$ of systemic thromboemboli arise from within the heart (Mitchell and Cotran 2003). However, in this case there was no evidence of cardiac disease. The thrombus found was mature, being over 16 hours old and found overlying and attached to an area of endothelial necrosis. Unlike the thrombus, the age of the endothelial damage could not be estimated; it may have caused thrombus formation, or have resulted from it.

Blood is known to flow in a laminar fashion within blood vessels, with cells and platelets running centrally separated from the endothelium by a zone of plasma. Any disruption of this pattern, either anatomically or due to pathological processes, causes turbulence with pockets of stasis. Platelets come into contact with endothelium promoting endothelial activation, whilst the balance of pro- and anti-thrombotic factors is disrupted in favour of the pro-thrombotic. Thus the damage observed in this case may have secondary to turbulence, similar to the cumulative damage to the internal iliac arteries at exercise, proposed as a mechanism for AIFT (Maxie and Physick-Sheard 1985). Alternatively or in addition, once present the thrombus would have caused turbulence at the site which would potentiate and promote further clot formation.

In man, ulcerated atherosclerotic plaques, aneurysms, intracardiac turbulence (e.g. valve stenosis, insufficiency, prosthetic heart valves) or hyperviscosity syndromes (e.g. polycythemia, sickle cell anaemia) may promote turbulence and thereby thrombus formation. The intimal plaques which have been found in horses affected by AIFT (Azzie 1996, Maxie and Physick-Sheard 1985) were not present in this case. 
Hypercoagulability is considered a less common cause of thrombosis in man and results from primary (genetic) or secondary (acquired) alterations in the clotting cascade. The most common primary cause of hypercoagulability in man is factor $\checkmark$ gene or prothrombin gene mutations, whilst primary defects in clotting are extremely rare in the horse. It seems highly unlikely that the mare reached the age of 11 years with a primary
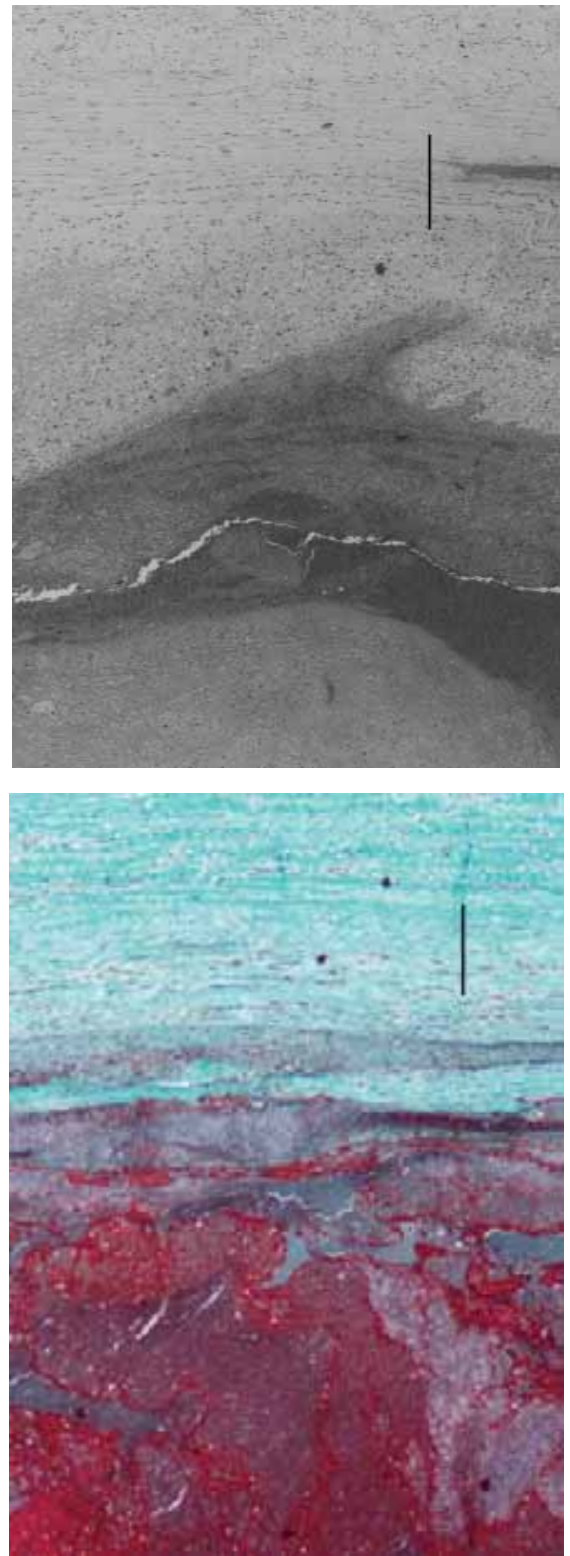

Fig 5 Histological transverse sections (site B) with thrombus formation, HE (a) and MSB stain (b). Bar $250 \mu \mathrm{m}$.

Histologischer Schnitt in Sektion B mit Thrombusbildung, HE- (a) und MSB-Färbung (b). Maßstab $250 \mu \mathrm{m}$.

defect in clotting; furthermore, clotting times were measured and were normal. Acquired hypercoagulability states in man are generally multifactorial, including increasing age, oral contraceptive use, smoking, obesity and nephrotic syndrome (Vaideeswar and Deshpande 2001). In contrast, the most common acquired hypercoagulability syndrome seen in horses is that occurring as a result of endotoxaemia (Dallap 2004). However, no clinical or pathological evidence of endotoxaemia or systemic disease were found and the mare appeared completely normal up until a few hours before referral.
Clinical signs of hind limb ischaemia are seen in human when over $25 \%$ of the arterial lumen has been occluded (Dotter et al 1983). Whether this factor is applicable in the case of a forelimb is questionable. Even if it was, complete physical removal of the thrombus was the only treatment option available since obstruction was complete. Surgical removal of thrombus in AIFT has been described in 14 cases with a pro-

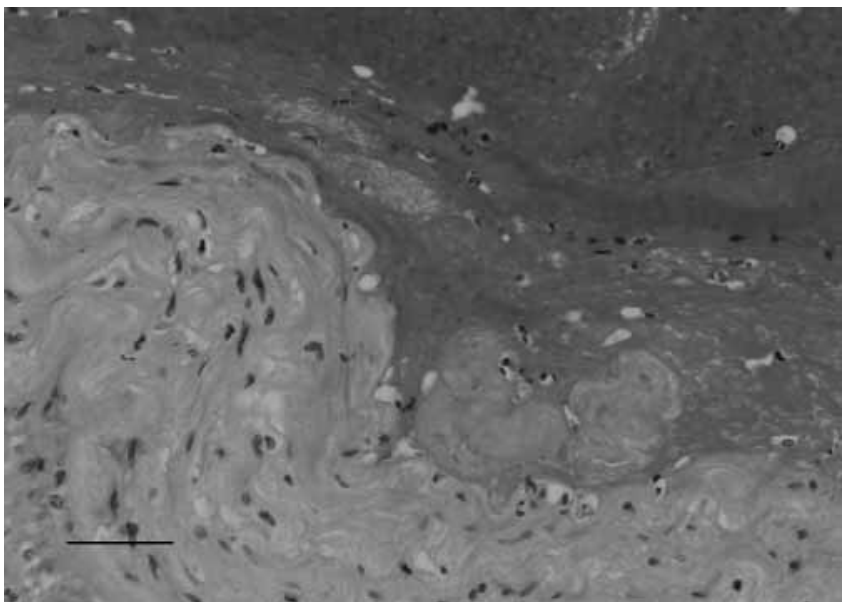

Fig 6 Lower tunica media, upper thrombus. Mediacytes exhibit a moderate cytoplasmic vacuolation (degeneration). The thrombus is composed of fibrin, erythrocytes and leucocytes. Endothelial cells exhibit focal hyperplasia and necrosis. HE stain, bar $50 \mu \mathrm{m}$.

Unten Tunica media, oben Thrombus. Mediazyten weisen auf moderate zyłoplasmatische Vakuolosierung (degeneration) hin. Der Thrombus besteht aus Fibrin, Erytrozyten und Leukozyten. Endothelzellen weisen auf fokale Hyperplasie und Nekrose hin. HE-Färbung, Maßstab $50 \mu \mathrm{m}$.

gnosis of $60 \%$ to regain the previous level of athletic activity (Brama et al. 1989, Rijkenhuizen 2006 personal communication). The Fogarty catheter could have been introduced in to the brachial artery in a similar way to the femoral artery in a hind limb. At the time of diagnosis it was impossible to scan or otherwise ascertain the proximal extent of the thrombus. This, as well as the sudden onset and severity of clinical signs, meant that surgery was not considered an option. Drug therapy in man aims to modify thrombosis by changing rate of fibrin formation, platelet adhesion and fibinolysis (Rang et al. 1995). A number of thombolytic drugs are available for clinical use in man, including streptokinase and urokinase, which have been shown to significantly reduce mortality when used in patients with myocardial infarction (ISIS 1988). By contrast, the medical treatment of cases of equine AIFT is palliative at best, aiming to delay thrombus development until a collateral circulation can develop and no treatment regime has been shown to consistently improve outcome (Dyson and Worth 1997). Drug therapy carried out early in the disease process before arterial occlusion and onset of clinical signs may have been effective. By the time of examination it was considered inappropriate due to the complete obstruction and severe distress the mare was suffering.

In summary, a mature thrombus was found in the proximal brachial artery, the cause of which could not be ascertained. The presentation, diagnosis and post-mortem pathology demonstrated important differences with AlFT, most importantly the precipitation of signs following minimal exercise and failure to improve with time. To the authors' knowledge this is the first case of primary proximal arterial occlusion due to thrombosis to be described in the forelimb of the horse. 
The case described was examined and treated at the University of Liverpool's Philip Leverhulme Equine Hospital in February 2005. We gratefully acknowledge Mr. Stevan Orrell MRCVS, the veterinarian who carried out initial examination and treatment of the mare prior to referral. Richard Coome$r$ 's clinical training scholarship is funded by the Horserace Betting Levy Board.

\section{Manufacturer}

a Virbaxyl 10\% Injectable Sedative, Virbac UK Ltd., Cambridge Innovation Centre II, Cambridge Science Park, Milton Road, Cambridge, CB4 4WE, UK.

\section{Literature}

Azzie M. A. J. (1969): Aortic iliac thrombosis of thoroughbred horses. Equine Vet J 1,113-116

Edwards G. B. and Allen W. E. (1988): Aorto-iliac thrombosis in two horses: clinical course of the condition and use of real-time Ultrasonography to confirm diagnosis. Equine Vet J 20, 384-387

Brama P. A., Rijkenhuizen A. B., van Swieten H. A. and Warmerdam E. P. (1996): Thrombosis of the aorta and the caudal arteries of the horse; additional diagnostics and a new surgical treatment. Vet $Q$, 18 Suppl 2, 85-89

Dallap B. L. (2004): Coagulopathy in the equine critical care patient In: Wilkins PA, ed. Critical care for all ages. Vet Clin North Am, Philadelphia, PA. WB Saunders, 231-251

Dotter C. T., Grüntzig A., Schoop W. and Zeitler E. (1983: Percutaneous Transluminal Angioplasty. Berlin: Springer-Verlag

Dyson S. J. and Worth L. (1997): Aortoiliacofemoral thrombosis. In: Robinson N. E., ed. Current Therapy in Equine Medicine, 4th ed. Philadelphia, PA: WB Saunders, 267-268

International Study of Infarct Survival, ISIS (1988) Randomised trial of intravenous streptokinase, oral aspirin, both, or neither among 17,187 cases of suspected myocardial infarctions. Lancet; ii:349-360 Jubb K. V. F., Kennedy P. C. and Palmer N. (1993): Pathology of Domestic Animals, vol. 3, 4th ed. San Diego: Academic Press, 61-62

Maxie M. G. and Physick-Sheard P. W. (1985): Aortic-iliac thrombosis in horses. Vet Pathol 22, 238-249

Merillat L. A. and Merillat E. (1907): Thrombosis of the iliac arteries of the horse. Am Vet Rev 31, 89-97,252-265

Mitchell R. N. and Cotran R. S. (2003): Haemodynamic disorders, thrombosis and shock. In: Kumar V., Cotran R. S., Robbins S. L., ed. Basic Pathology, 7th ed, Philadelphia, PA: WB Saunders, 90-98

Rang H. P., Dale M. M. and Ritter J. M. (1995): Haemostasis and Thrombosis. In: Pharmacology, 3rd ed. Edinburgh: Churchill Livingstone, 331-350

Rose P. L., Watkins J. P. and Auer J. A. (1984): Femoral fracture repair complicated by vascular injury on a foal. J Am Vet Med Assoc 185, 795-797

Vaideeswar P. and Deshpande J. R. (2001): Non-athersclerotic aorto-arterial thrombosis: A study of 30 cases at autopsy. J Postgrad Med 41, 8-14

Witz M., Lehman J., Shnaker A. and Korzets Z. (2004): Acute subclavian and brachial artery thrombosis as a complication of the nephrotic syndrome. Isr Med Assoc J 6, 44 1-442

Richard P. C. Coomer, MA VetMB CertES (Soft Tissue) MRCVS

Equine Division, Faculty of Veterinary Science

University of Liverpool

Leahurst, Chester High Road, Neston, South Wirral, CH64 7TE, UK

richcoomer@hotmail.com

\section{Kaufuntersuchung}

17.-18. Februar

Berlin-Brandenburgische Akademie der Wissenschaften

Bodo Hertsch Bernhard Ohnesorge Dietrich Plewa Peter Stadler

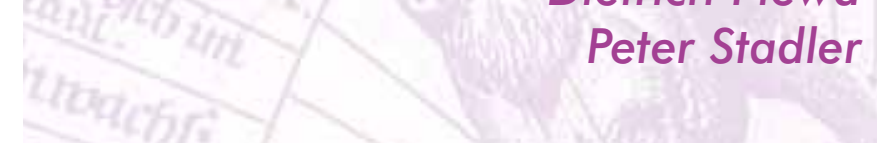

Vorbedingungen für die Kaufuntersuchung Auftraggeber, Verkäufer, Käufer, Tierarz†

Allgemeine Vertragsbedingungen Erklärung des Verkäufers und AuftragUmfang und Ablauf der klinischen Untersuchung Röntgenuntersuchung

Zur Rolle des Röntgenleitfadens Die radiologische Verurteilung des Pferdes Ergänzende Untersuchungen Bewertung der Ergebnisse Honorierung Aufklärung und Dokumentation Haftungsrisiko Haftung gegenüber Dritten Vertragsmäßige Verkürzung der Gewährsfrist Die KU als Grundlage von Rechtsstreitigkeiten Entwicklung der Rechtsprechung seit 2002

Beispielhafte Kasuistiken

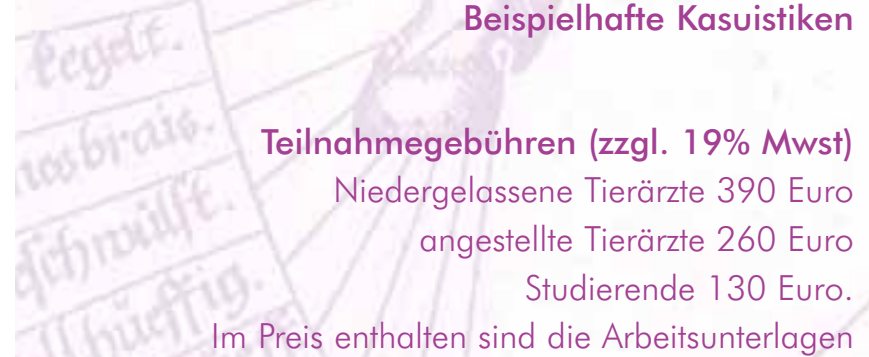

und Kaffeepausen.

(30 Euro Rabatt für Pferdeheilkunde-Abonnenten)

Information und Anmeldung Curricula

Postfach 0805 39, 10005 Berlin Telefon (01 76) 23411422 Fax (0 30) 28040452 E-Mail:pfd@curricula.cc www.curricula.cc 